\title{
The maximum capacity of the liver of the adult dairy cow to metabolize ammonia
}

\author{
By H. W. SYMOINDS, DENISE L. MATHER AND K. A. COLLIS* \\ Agricultural Research Council, Institute for Research on Animal Diseases, Compton, \\ Newbury, Berkshire RG16 ONN
}

(Received 21 April 1980-Accepted 5 June 1981)

\begin{abstract}
1. Three adult dairy cows were fitted with cannulas in a mesenteric, portal, hepatic and jugular vein and a carotid artery. They received infusions of step-wise increasing amounts of ammonia as ammonium acetate via a mesenteric vein until $\mathbf{N H}_{3}$ intoxication occulred. Sodium acetate was used in control infusions. The maximum rate of uptake of $\mathrm{NH}_{3}$ by the liver and the conce ntrations of glucose, urea, lactate, acetate and bilirubin in blood were measured.

2. During the infusions of ammonium acetate the liver extracted almost all the $\mathrm{NH}_{3}$ present in the portal vein until an infusion rate of approxirntately $15.0 \mathrm{mmol} / \mathrm{min}$ was reached. The maximum capacity of the liver to remove $\mathrm{NH}_{3}$ during its first pass was on average $1.84 \mathrm{mmol} / \mathrm{min}$ per $\mathrm{kg}$ wet weight. The cows became intoxicated when arterial plasma ammonia concentrations reached $0.8 \mathrm{mmol} / \mathrm{l}$. Concentrations of $\mathrm{NH}_{3}$ in jugular venous blood were between 66 and $74 \%$ of those in the carotid.
\end{abstract}

In ruminants much of the protein and non-protein nitrogen in the diet is normally metabolized to ammonia by rumenal micro-organisms. Some of this $\mathbf{N H}_{\mathbf{3}}$ is incorporated into microbial protein but a proportion of it (depending upon rumen $\mathrm{pH}$ ) is absorbed through the rumen wall. If this $\mathrm{NH}_{3}$ reaches the systemic circulation it is very toxic. In most physiological conditions it is converted in the liver to the less toxic urea thus keeping the $\mathrm{NH}_{3}$ concentration in the systemic circulation low. However, under certain circumstances, for example when cattle are fed rations containing large amounts of either readily degradable protein or non-protein nitrogen the amount of $\mathrm{NH}_{3}$ which enters the portal circulation may exceed the rate at which the liver can metabolize it. The concentration of $\mathrm{NH}_{3}$ in the systemic circtiation will then increase until, when arterial $\mathrm{NH}_{3}$ concentrations are approximately $1.0 \mathrm{mmol} / 1$, the cow shows clinical signs of $\mathrm{NH}_{3}$ intoxication (Davidovitch et al. 1977).

One factor which will affect the susceptibility of the dairy cow to $\mathrm{NH}_{3}$ intoxication is, therefore, the capacity of its liver to metabolize $\mathrm{NH}_{3}$. When systemic $\mathrm{NH}_{3}$ concentrations increase there is also an increase in blood concentrations of glucose, lactate, pyruvate and free fatty acids (Visek, 1972; Barej et al. 1974; Garwacki et al. 1979). The capacity of the bovine liver to metabolize $\mathrm{NH}_{3}$ has not been measured in vivo.

This report describes an experiment in which $\mathrm{NH}_{3}$, as ammonium acetate $\left(\mathrm{NH}_{4} \mathrm{Ac}\right)$, was infused in increasing amounts into a mesenteric vein of three adult cows until they became intoxicated. The uptake of $\mathrm{NH}_{3}$ by the liver was measured by determining the $\mathrm{NH}_{3}$ concentration in portal and hepatic venous blood.

\section{MATERIALS AND METHODS}

\section{Animals}

Three mature, non-pregnant, non-lactating Friesian $\times$ Ayrshire cows weighing $450-500 \mathrm{~kg}$ were used. Silicone rubher cannulas were implanted surgically in a mesenteric, portal, hepatic and jugular vein and a carotid artery by a combination of the procedures described 
by Symonds \& Baird (1973) and Baird et al. (1975). All cows received $4.5 \mathrm{~kg}$ hay and $3 \mathrm{~kg}$ dairy concentrate daily, fed in two equal portions at 07.30 and 14.30 hours.

\section{Experimental procedure}

To increase portal venous $\mathrm{NH}_{3}$ concentrations a solution of $\mathrm{NH}_{4} \mathrm{Ac}$ (approximately $2.0 \mathrm{mmol} / \mathrm{ml}$ ) was infused into a mesenteric vein using a peristaltic pump (Watson-Marlow HR Flow Inducer, Watson Marlow Air Pump Co., Falmouth, Cornwall).

Each infusion was started at approximately 10.30 hours at a rate of $1.8 \mathrm{mmol} \mathrm{NH}_{4} \mathrm{Ac} / \mathrm{min}$. At $15 \mathrm{~min}$ intervals the rate was increased by approximately $2 \mathrm{mmol} / \mathrm{min}$, the actual amount infused being measured by weighing the reservoir containing the infusion fluid. Blood samples were collected simultaneously from the cannulas in portal, hepatic, jugular and carotid vessels $14 \mathrm{~min}$ after each increase in rate. The infusions were stopped when the cows became recumbent due to $\mathrm{NH}_{3}$ intoxication (after 150-160 min of infusion). At least $7 \mathrm{~d}$ after the infusion of $\mathrm{NH}_{4} \mathrm{Ac}$, an infusion of sodium acetate $(\mathrm{NaAc})$ was given to each cow using the same programme of increases in infusion rate.

\section{Blood sampling and analytical procedures}

Samples of blood were taken into perchloric acid $(60 \mathrm{~g} / 1)$; into bottles containing $10 \mathrm{u} / \mathrm{ml}$ of heparin; and into bottles containing an ammonium fluoride/oxalate mixture (Anderson, 1969) for glucose estimation by an automated glucose-oxidase method (Sigma, 1970). Plasma was separated from the heparinized blood after centrifugation at $2000 \mathrm{rev} / \mathrm{min}$. The concentrations of $\mathrm{NH}_{3}$ in plasma were determined by a procedure based on the enzymic conversion of $\alpha$-ketoglutarate into glutamate (Sigma, 1978) using a manual Vitatron Universal Photometer UFD. Plasma urea was analysed using the automated method described by Rowlands et al. (1974). Plasma total bilirubin concentrations were estimated by the Technicon method AAII-18 (Technicon Instruments). Acetate concentration in the neutralized $\mathrm{HClO}_{4}$ extracts of whole blood was determined by the method of Snoswell et al. (1978) and lactate by the method of Bergmeyer (1963).

\section{RESULTS}

The changes which occurred in the mean plasma $\mathrm{NH}_{3}$ and whole blood glucose concentrations during the infusion of $\mathrm{NH}_{4} \mathrm{Ac}$ and $\mathrm{NaAc}$ into the three cows are shown in Fig. 1. Table 1 records the mean $( \pm \mathrm{SE})$ concentrations of $\mathrm{NH}_{3}$, glucose, urea, lactate, acetate and bilirubin in portal and hepatic venous blood and carotid arterial blood before the infusion of either salt and in the last samples taken when the cows were intoxicated or at a comparable point during the $\mathrm{NaAc}$ infusion.

\section{Clinical changes}

The infusions of $\mathrm{NaAc}$ produced no adverse clinical signs. The animals drank more and passed more urine as the amount of acetate infused increased. When $\mathbf{N H}_{4} \mathrm{Ac}$ was infused there was an increase in the frequency of urination and small quantities of looser than normal faeces were passed. When the infusion rate was increased to $18.0 \mathrm{mmol} / \mathrm{min}$ (arterial plasma concentration $0.12-0.26 \mathrm{mmol} / \mathrm{l})$ the cows became apprehensive and restless and their respiratory movements were exaggerated. At an infusion rate of between 21.0 and $24.0 \mathrm{mmol} / \mathrm{min}$ (arterial concentration $0.66-0.76 \mathrm{mmol} / \mathrm{l}$ ) the cows became unsteady, with increased muscular fasciculation over the hind-quarters, shoulders and flank. Very fluid faeces were passed. When the infusion rate was increased to $27.0 \mathrm{mmol} / \mathrm{min}$ in cows $A$ and $B$ and $31 \mathrm{mmol} / \mathrm{min}$ in cow $\mathrm{C}$ (arterial concentration $0.79-0.95 \mathrm{mmol} / \mathrm{l}$ ) the cows became recumbent and the infusion was stopped. The cows usually stood up within $20 \mathrm{~min}$ of stopping the infusion. 


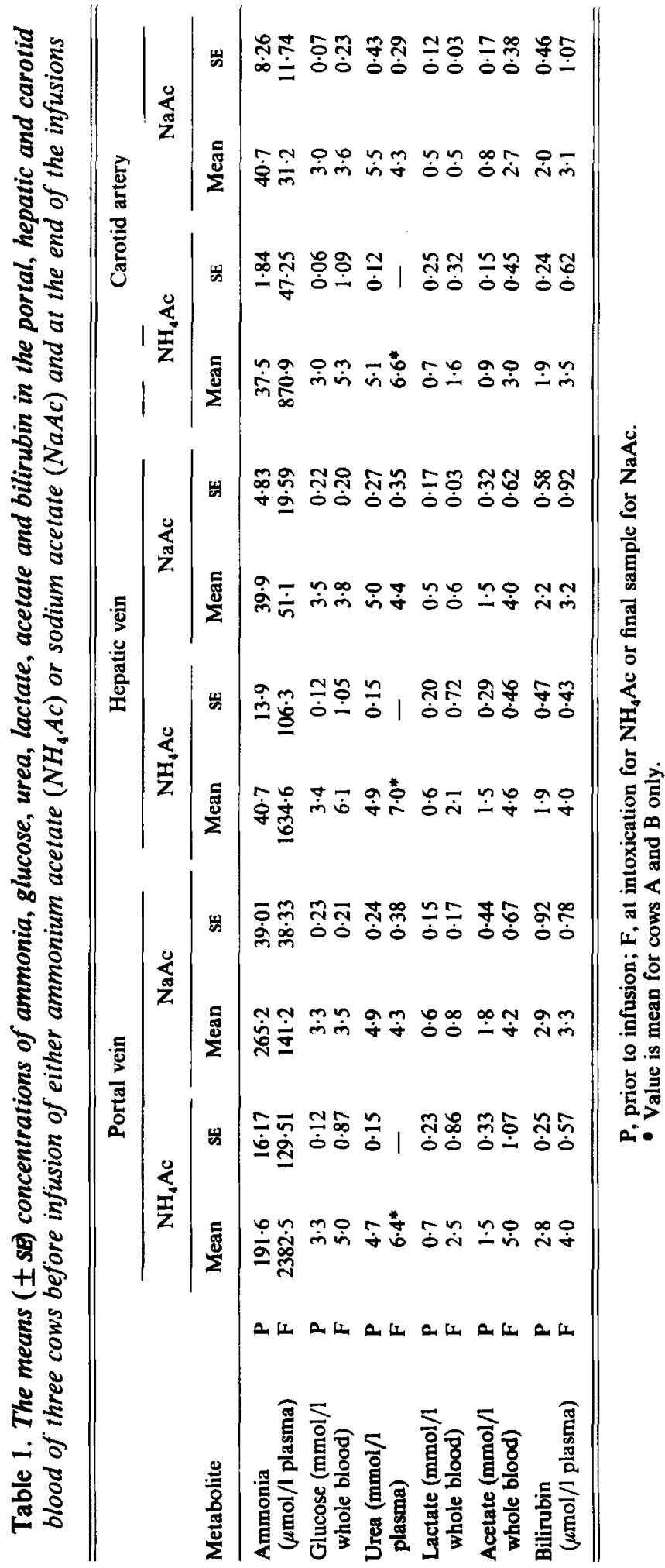




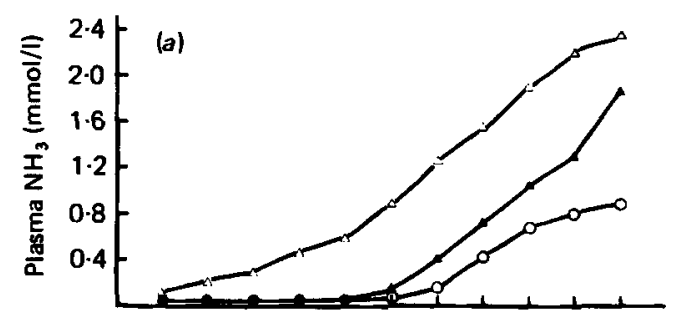

(b)

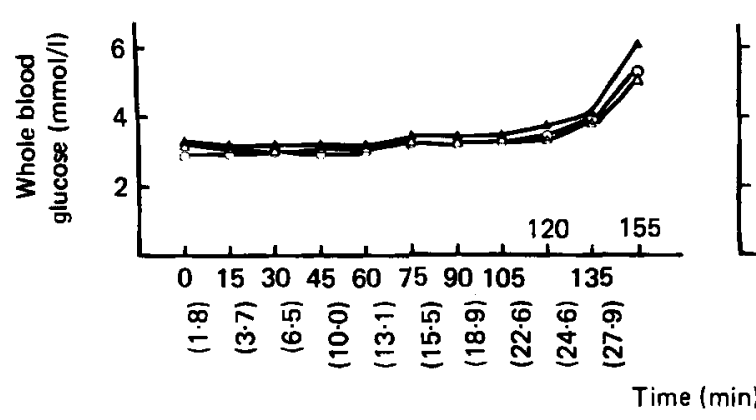

Fig. 1. The changes in portal $(\Delta-\Delta)$, hepatic $(\Delta-\Delta)$ and carotid $(\mathrm{O}-\mathrm{O})$ plasma $\mathrm{NH}_{3}$ concentration $(\mathrm{mmol} / \mathrm{l})$ and whole blood glucose concentration ( $\mathrm{mmol} / \mathrm{l})$ during $(\mathrm{a})$ an infusion of ammonium acetate and $(b)$ sodium acetate. Values in brackets denote $\mathrm{NH}_{3}$ infusion rate ( $\mathrm{mmol} / \mathrm{min}$ ).

\section{Effect upon $\mathrm{NH}_{3}$ metabolism}

Before infusion the concentrations of $\mathrm{NH}_{3}$ in the arterial plasma were $0.040,0.034$ and $0.039 \mathrm{mmol} / 1$ and there were no significant increases in these concentrations until the infusion rate reached 15,12 and $17 \mathrm{mmol} / \mathrm{min}$ for cows $\mathrm{A}, \mathrm{B}$ and $\mathrm{C}$ respectively. Thereafter, arterial plasma concentrations of $\mathrm{NH}_{3}$ increased indicating that the liver was no longer able to remove all the $\mathrm{NH}_{3}$ present in portal blood. When the cows became recumbent their arterial $\mathrm{NH}_{3}$ concentrations were $0.95,0.79$ and $0.87 \mathrm{mmol} / 1$ and their portal plasma $\mathrm{NH}_{3}$ concentrations were $2 \cdot 1,2.6$ and $2.4 \mathrm{mmol} / 1$ in cows $\mathrm{A}, \mathrm{B}$ and $\mathrm{C}$ respectively.

The liver weights of the cows were: cow A $7.1 \mathrm{~kg}$, cow B $9 \mathrm{~kg}$ and cow C $8.2 \mathrm{~kg}$ and the mean $( \pm \mathrm{SE})$ maximum capacity of the livers to remove $\mathrm{NH}_{3}$ at its first pass was $1.84 \pm 0.25 \mathrm{mmol} / \mathrm{min}$ per $\mathrm{kg}$ liver.

The NaAc infusion had no effect upon arterial plasma $\mathrm{NH}_{3}$ concentrations. $\mathrm{NH}_{3}$ concentrations were higher in the portal than in the hepatic vein indicating that $\mathrm{NH}_{3}$ was being absorbed from the gut.

\section{Effect upon glucose metabolism}

Before infusion the normal concentration of glucose in arterial whole blood was approximately $3 \mathrm{mmol} / \mathrm{l}$ (Table 1). A small increase in concentration occurred only during the latter stages of the infusion of $\mathrm{NH}_{4} \mathrm{Ac}$ (Fig. 1, Table 1) in cows $\mathrm{A}$ and $\mathrm{B}$, and a larger increase in cow $\mathrm{C}$ which began when the infusion rate was $16 \mathrm{mmol} \mathrm{NH}_{3} / \mathrm{min}$.

\section{Effect upon urea metabolism}

The concentration of urea in the plasma from all three vessels of cows $A$ and $B$ increased during the $\mathrm{NH}_{4} \mathrm{Ac}$ infusion and decreased during the $\mathrm{NaAc}$ infusion (Table 1). In cow $\mathrm{C}$, urea concentrations decreased during both infusions. No reason for this decrease in urea 
concentration in cow $\mathrm{C}$ diring the $\mathrm{NH}_{4} \mathrm{Ac}$ infusion could be identified but its data were not included in the calculation of the mean urea concentrations for this infusion given in Table 1. The final concentrations in cow $C$ were $3.9,4.3$ and $4.7 \mathrm{mmol} / 1$ of portal, hepatic and carotid plasma respectively.

\section{Effect upon lactate metabolism}

During the infusion of $\mathrm{NH}_{4} \mathrm{Ac}$ blood lactate concentrations increased. In cow $\mathrm{A}$ this increase was observed only in the final sample but in cows $B$ and $C$ the concentration of lactate increased when the infusion rate reached $18 \mathrm{mmol} / \mathrm{min}$. During the $\mathrm{NaAc}$ infusion there was little change in liactate concentrations in cows $\mathrm{A}$ and $\mathrm{B}$ but a $220 \%$ increase in cow C.

\section{Effect upon acetate metabolism}

There was an uptake of acelate by the head, demonstrated by the fact that the concentration in jugular blood was lower than that in carotid blood. In cows A, B and C arterial acetate concentrations were $37.5,33.7$ and $49.8 \%$ of portal acetate concentrations respectively, whether or not $\mathrm{NH}_{3}$ was teing infused. This difference demonstrates that the uptake of acetate by peripheral tissues reduced the amount returning in vena caval blood and that $\mathrm{NH}_{3}$ had little effect upon the uptake.

\section{Effect upon bilirubin}

There was an increase in bilirubin concentration in all vessels during both infusions.

\section{DISCUSSION}

The results presented show that until its concentration exceeded approximately $1.0 \mathrm{mmol} / \mathrm{l}$ most of the $\mathrm{NH}_{3}$ in the portal blood was extracted during its first passage through the liver. The maximum capacity of the liver to extract $\mathrm{NH}_{3}$ was approximately $1.84 \mathrm{mmol} / \mathrm{min}$ per kg liver weight.

The relevance of these results is principally to those animals whose rumen micro-organisms and hepatic enzyme systems have not been adapted to high protein intakes. At the point at which the hepatic capacily was exceeded (after $90 \mathrm{~min}$ of infusion) approximately $13 \mathrm{~g}$ of $\mathrm{NH}_{3}$ had been infused but acute intoxication occurred after approximately $39 \mathrm{~g} \mathrm{NH}_{3}$ had been infused. Therefore, it appears that the rate of input was more important than the total input.

Cattle grazing pasture which has a high soluble protein content may well be exposed to amounts of $\mathrm{NH}_{3}$ similar to those used in these infusions. A grazing cow may consume up to $500 \mathrm{~g} / \mathrm{d}$ of $\mathrm{N}$ (assuming an $18 \mathrm{~kg} \mathrm{DM} /$ day intake, of $18 \%$ protein content). In calves fed fresh pasture, up to $30-40 \%$ of the protein ingested may disappear anterior to the duodenum, and is presumebly converted to $\mathrm{NH}_{3}$ in the rumen (Beever et al. 1980). If a similar percentage was lost in adult cattle it would represent up to $200 \mathrm{~g} \mathrm{~N}\left(\sim 14 \mathrm{~mol} \mathrm{NH}_{3}\right.$ or $25 \mathrm{mmol} / \mathrm{min}$ ) during a grazing period of approximately $10 \mathrm{~h}$. The amount of $\mathrm{NH}_{3}$ reaching the liver therefore may be greater than the liver's capacity to metabolize it and result in an increase in systemic $\mathrm{NH}_{3}$ concentration. Although the conditions in the rumen, such as $\mathrm{pH}$, will influence the rate of production and absorption of $\mathrm{NH}_{3}$, it is possible that a subclinical $\mathrm{NH}_{3}$ intoxicetion could occur, one manifestation of which could be the frequent passage of loose fieces.

Severe signs of intoxication occurred when the arterial concentration exceeded $0.8 \mathrm{mmol}$ $\mathrm{NH}_{3} / 1$. The concentrations in jugular plasma were 66-74\% lower than the arterial plasma concentrations. This reduction and the nervous signs exhibited were presumably due to the brain taking up $\mathrm{NH}_{3}$. Davidovitch et al. (1977) observed values of 1.05 and $0.68 \mathrm{mmol}$ of 
$\mathrm{NH}_{3}$, in the carotid and jugular blood respectively, of cows showing signs of intoxication after receiving urea intraruminally.

Blood glucose concentrations increased only when the cows were severely intoxicated. The hyperglycaemia associated with $\mathrm{NH}_{3}$ intoxication has been attributed to the combined effects of reduced utilization of glucose by peripheral tissues and increased hepatic glycogenolysis caused by release of adrenalin. Adrenalin would also reduce or inhibit insulin secretion and thereby prolong the hyperglycaemia. Ammonia may, however, also have a direct action. Barej \& Harmeyer (1979) observed that after an infusion of $\mathrm{NH}_{4} \mathrm{Cl}, \mathrm{NH}_{3}$ concentrations in plasma returned to normal much more rapidly than concentrations of glucose and considered that the ammonium ion had an inhibitory action on the pancreatic $\beta$ cells. Prior et al. (1971) showed that, in the rat, hyperglycaemia induced by $\mathbf{N H}_{3}$ was refractory to insulin. It is likely that in the experiments described here the hyperglycaemia arose at least in part from an increase in hepatic glucose production which occurred only when the cows were severely intoxicated.

The authors thank Mrs. C. Copp for performing the plasma enzyme analyses and $\mathrm{Mr}$ P. Brookes for the glucose, urea and bilirubin assays.

\section{REFERENCES}

Anderson, D. M. (1969). J. comp. Path. 79, 525.

Baird, G. D., Symonds, H. W. \& Ash, R. (1975). J. agric. Sci., Camb. 85, 281.

Barej, W., Garwacki, S., Kulasek, G. \& Wiechetek, M. (1974). Acta Physiol. Polon. 5, 157.

Barej, W. \& Harmeyer, J. (1979). Q. Jl Expl Physiol. 64, 31.

Beever, D. E., Ulyatt, M. J., Thomson, D. J., Cammell, S. B., Austin, A. R. \& Spooner, M. C. (1980). Proc. Nutr. Soc. 39, 66A.

Bergmeyer, H. U. (ed.) (1963). Methods of Enzymic Analysis. New York and London: Academic Press.

Davidovitch, A., Bartley, E. E., Chapman, T. E., Bachtle, R. M., Dayton, A. D. \& Frey, R. A. (1977). J. anim. Sci. 44, 702.

Garwacki, S., Wiechetek, M. \& Barej, W. (1979). Q. Jl Expl Physiol. 64, 23.

Prior, R. L., Clifford, A. J., Gibson, G. E. \& Visek, W. J. (1971). Am. J. Physiol. $221,432$.

Rowlands, G. J., Little, W., Manston, R. \& Dew, A. M. (1974). J. agric. Sci., Camb. 83, 27.

Sigma (1970). Sigma Tech. Bull. No. 970.

Sigma (1978). Sigma Tech. Bull. No. 170-UV.

Snoswell, A. M., Costa, N. D., McLean, J. G., Baird, G. D., Lomax, M. A. \& Symonds, H. W. (1978). J. Dairy Sci. 45, 331.

Symonds, H. W. \& Baird, G. D. (1973). Res. vet Sci. 14, 267.

Visek, W. J. (1972). Fedn Proc. Fedn Am. Socs exp. Biol. 31, 1178. 